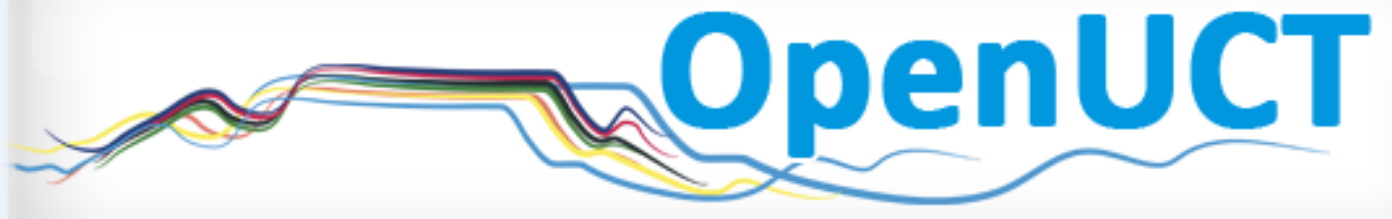

This is the post-print of Bangeni, B. \& Kapp, R. 2007. Shifting language attitudes in linguistically diverse learning environment in South Africa. Journal of Multilingual and Multicultural Development. 28(4): 253-269. DOI: 10.2167/jmmd495.0.

It is made available according to the terms of agreement between the author and the journal, and in accordance with UCT's open access policy available:

http://www.openuct.uct.ac.za/sites/default/files/UCTOpenAccessPolicy.pdf, for the purposes of research, teaching and private study. 


\title{
Shifting Language Attitudes in a Linguistically Diverse Learning Environment in South Africa
}

\author{
Bongi Bangeni and Rochelle Kapp \\ Academic Development Programme, CHED, University of Cape Town, \\ Rondebosch, South Africa
}

This paper draws on post-structuralist theories on language and identity to explore the shifting language attitudes of 15 'black' students over the course of their undergraduate studies at a historically 'white' South African university. All the students speak an indigenous language as their first language. Those students who have been educated in racially mixed schools are relatively at ease in the environment and are able to straddle racial and linguistic boundaries. Those who have been educated in working-class, ethnically homogenous schools enter the institution with a strong desire to preserve their home languages and home identities. For them, English is equated with 'whiteness'. The paper describes the process through which this equation is questioned as English and institutional discourses become more dominant in students' lives, and as relationships with their home communities become strained. By the time the students enter their senior undergraduate years, a shared speech code emerges. The authors argue that this code signals students' dual affiliation to English (and the cultural capital it represents) and to their home identities. In mixing languages across boundaries of school background and across traditional ethnic barriers, the code also signals students' shared group identity as first-generation university students in post-Apartheid South Africa.

Keywords: English second language, language attitudes, identity

\section{Introduction}

In the 'new' South Africa a policy of multilingualism has been adopted that recognises 11 official languages and enshrines the language rights of the individual in the bill of rights of its 1996 Constitution. Through the establishment of an independent statutory body, the Pan South African Language Board, the State commits itself to taking 'practical and positive measures to elevate the status and advance the use of indigenous languages' (Republic of South Africa, 1996: 2). The emphasis is on promoting the status of indigenous languages (status planning), developing the languages themselves (corpus development) and increasing the numbers of users (acquisition development).

Twelve years into our democracy, there is little sign that the policy of multilingualism is anything other than a symbolic gesture. It seems that English has retained (some would say increased) its status as the language of the powerful in politics, business, the legal profession and the media (Young, 1995). These practices can partially be explained by the country's continued 
economic dependence on the metropole (see Ndebele, 1987). The favourable attitudes towards English shown by African-language speakers also have to be viewed in the light of the long history of the language as a symbol of education, culture and modernisation, and of pre-liberation resistance to Nationalist Party attempts to enforce Afrikaans and mother tongue education at various points (see Hirson, 1979). However, these generalised explanations do not help us to gain a nuanced understanding of the language attitudes and practices of young South Africans, who have mainly grown up in a postApartheid South Africa. At a time when there are moves to implement multilingual policies in the tertiary context (see Department of Education, 2002), it seems fitting to attempt to understand how young indigenous language speakers are positioning themselves in relation to English and their home languages.

Our research site is an English-medium, historically 'white' 1 university. At present, about $65 \%$ of students declare English as their first language. The remaining $35 \%$ of students have home languages that include all of the official indigenous languages, and approximately 54 African, European and Asian languages. It is important to note that given that 'black' students now constitute just over $50 \%$ of the university's student population, this means that large numbers of 'black' students regard English as a first language, either because it is a home language and/or because they took English as a first language at school. The legacy of Apartheid is such that race and language are still generally indicators of social class position; however, these figures indicate an emerging class division (also noted by de Kadt, 2005) among 'African' and 'coloured' students for whom an African language or Afrikaans is a home language. While an increasing number of these students are now being educated at relatively well resourced, middle-class, formerly 'white', now racially mixed (ex-model $C$ ) schools, others are emerging from former D.E.T. and D.E.C.2 township schools, which were designated for 'African' and 'coloured' students respectively, and are by contrast relatively ethnically homogenous, working-class and poorly resourced. Still others are emerging from former 'model C' schools that have been vacated by 'white' students in the 'new' South Africa, leaving a population consisting almost entirely of African-language speakers who are taught by 'white' English- and Afrikaansspeaking teachers.

Drawn from the first three years (2002Á2004) of our longitudinal study of 20 undergraduate Humanities' students from disadvantaged backgrounds, the 15 students who are the subject of this paper are all from home backgrounds where an indigenous language is the medium of communication. Their first languages include isiXhosa, isiZulu, seSotho, seTswana, siSwati and Afrikaans. Their ages ranged from 18 to 27 . Although all the students were placed on an academic literacy course in their first year, their schooling backgrounds reflect the full diversity described above, with five of them having studied English as a first language at school. In this paper we explore students' attitudes to English in relation to their home languages over the course of their undergraduate degree at university. The paper describes the effects of schooling background on language attitudes and illustrates students' shifts in language attitudes and practices over the course of their undergraduate 
years. We argue that the changes are directly related to how they position and reposition themselves in relation to increasing access to, and fluency in a range of institutional discourses on the one hand, and increased closing off of connections to their township communities on the other.

\section{Theoretical Framework}

Language attitudes are traditionally defined by second-language theorists in terms of both perceptions and affect. According to McGroarty (1996: 5), they are

beliefs, emotional reactions and behavioural tendencies related to the object of the attitude .... Attitude is thus linked to a person's values and beliefs and promotes or discourages the choices made in all realms of activity, whether academic or informal.

However, second-language theorists using post-structural frameworks have argued that definitions such as these 'decontextualise, generalize and objectify', as they implicitly support 'a notion of identity as insular and static, passed down intact over time and across boundaries' (Morgan, 1997: 431). Our study draws on post-structuralist theories which view language attitudes and practices in multilingual contexts as being embedded in larger social, political, economic and historical contexts (Pavlenko \& Blackledge, 2004). Norton (2000: 5 ) argues that when people speak, they are not only exchanging information; it is through language that 'a person negotiates a sense of self within and across different sites at different points in time, and it is through language that a person gains access to Á or is denied access to powerful social networks that give learners the opportunity to speak'. Norton (2000: 5) uses the term 'identity' to 'reference how a person understands his or her relationship to the world, how that relationship is constructed across time and space, and how the person understands possibilities for the future'. This view includes a notion that identities are social, fluid, multiple and often contradictory.

We use a post-structuralist notion of 'discourse' to describe the accepted ways of 'saying-doing-being-valuing-believing' (Gee, 1990: 142) that characterise particular contexts. The basic premise of post-structuralist thinking on the subject is that discourses and discursive practices provide subject positions, and that individuals take up a variety of positions within different discourses (Canagarajah, 1999; Norton, 1995; Pavlenko \& Blackledge, 2004). Individuals constantly reposition themselves in relation to past and present interaction and resultant individual emotions such as joy, anger, insecurity, nostalgia, loss, fear and desire: 'the desire for recognition, the desire for affiliation, and the desire for security and safety' (Norton, 1997: 410). However, the degree to which individuals are able to reconstruct who they are is regulated by the extent to which they are able to access the material, linguistic, social and cultural resources that are valued within dominant discourses.

To become accepted members of dominant discourses, such as academic disciplines, individuals are required to act, think and speak within their ideological frameworks (Gee, 1990; Kress, 1989). For students from workingclass communities who are not fully proficient in English, this poses particular 
difficulties because they enter the institution without the 'cultural capital' (Bourdieu, 1991: 230) that the institution deems appropriate. Their home identities and languages are constructed as a problem that has to be fixed. Improving language and academic writing skills becomes inextricably tied to becoming proficient in the dominant discourse, which often poses particular tensions around identity. In this paper we show how students use their linguistic resources and Social Science discourses to process, rationalise and neutralise their ambivalence as they attempt to succeed in the academic environment, whilst retaining connections to home.

\section{Methodology}

Our research participants were all registered for a first-year academic literacy course in their first semester of study in 2002 and were taught by the authors of this paper in two separate classes. They volunteered to participate in our research project in March of that year and all remained active participants until the end of 2004. We have held four individual interviews with each student, as well as two focus group sessions and two informal gatherings. Our interviews were semi-structured, in order to facilitate comparison within each student's corpus over time, as well as comparison between students. However, we always also asked individual questions based on prior interviews and on our analyses of students' essays.

Baker (1993: 11) states that one of the difficulties of researching attitudes is that 'they are latent, inferred from the direction and persistence of external behaviour'. We have addressed this by constantly revisiting the same questions on language use and attitudes in the interviews over time. We have compared what students say in the interviews with other sources of information in the form of biographical questionnaires, three essays written for our course; essays from students' other courses over three years and students' own reflections on their writing. We have also familiarised ourselves with the content of students' other introductory, first-year courses and kept journals that document our classroom observations and informal interactions and conversations with students and between ourselves.

We have used these different sets of data to try to distinguish 'between how people think they ought to behave, how they say they behave, and how they are observed to behave' (Le Page \& Tabouret-Keller, 1985: 207). In this way we are able to trace their shifts in language attitudes and practices in relation to identity Á how they position and reposition themselves in their academic and home environments. The chief data sources for this paper are the interviews. Elsewhere we analyse students' writing development and writing personae (Bangeni \& Kapp, 2006; Kapp \& Bangeni, 2005). In this paper, we refer to their writing only insofar as it serves as additional substantiation for our analysis of students' relationship to, and fluency in, English and institutional discourses.

Our interview questions cover the areas of students' literacy and language development; their attitudes to language and academic literacy; their relationships to their chosen disciplines; their experiences of institutional culture and 
their relationships to home. The main questions relating to language attitudes and practices were:

How have you found the level of English here compared to school? Do you feel comfortable communicating in English?

Do you communicate in your home language with other students? When and where?

Do you think that you ought to be able to study through the medium of your home language?

We asked the above questions in order to ascertain the role that English plays in their undergraduate careers, if and why their attitudes towards their home languages change, and the implications of students' attitudes and practices for their literacy development and sense of self.

Recent studies by Dalvit and de Klerk (2005) and de Kadt (2005) provide necessary and valuable insight into contemporary language attitudes in particular South African universities. However, these studies provide limited insight into the fluidity of language attitudes and identity because they capture a single moment in the life of the students. Whilst the size of our study places limitations on the extent to which we are able to generalise across our institution, the longitudinal nature of the study and the range of data sources enable a depth of engagement with change in attitudes, as well as with the contradictions between what students say about their language use and their actual language and literacy practices.

\section{Maintaining Difference: 'It's White and You Don't Get To Speak Your Language Here'}

In their first interview, just over two months into their first semester, the students in our study who came from township schools (Andrew, Bulelwa, Garth, Lesedi, Michael, Noloyiso, Noluthando, S'busiso, Sizwe and Vuyani) all expressed their shock at the level of English in lectures and readings. The following comment from Vuyani, a Xhosa-speaker, was typical: 'the English here is different from the high school one, it is at another level. Whenever I read I am forced to use the dictionary'. Students identified their difficulties as being related not only to the English medium, but also to the type of literacy they were expected to produce. Most students had not written expository essays at schools, and battled to come to terms with the genre. According to Sizwe, a Xhosa-speaker: 'The level of English is too high here. At school it was not difficult. Here the questions are difficult and then you have to back up your answers'. Andrew, an Afrikaans-speaker, described a kind of paralysis when it came to writing essays: 'I would know something in my head and I would not know how to put it down'.

Students spoke of being silenced in class by the level and speed of the English spoken, and by early experiences of being judged as 'second-language' speakers and consequently stigmatised. Two students narrated experiences of being accused of not doing their own work because they had produced grammatically correct essays. Bulelwa (a Zulu/Sotho-speaker), who had 
always excelled at and enjoyed English at school, described the humiliation she experienced in her English literature course: 'Our English teacher on our first lecture came and asked us to write a page or paragraph on why we are here. Then she told me to go to the additional tutorial group and I took that very bad. It told me that I was a second-language speaker of English.' When she went to discuss the matter with her tutor, she was informed that because English is her second language, she should not expect to attain high marks for her essays.

Our data also reflect students' shock at the dominance of the English language in the university's social environment. Students described the environment as 'overwhelming', as 'a very English white academic culture' (Noloyiso, seSwati-speaker). According to Noluthando, a Tswana-speaker: 'It's white and you don't get to speak your language very easily here. Everybody speaks English here because everyone else speaks English'. Woolard (cited in Pavlenko \& Blackledge, 2002: 121Á122) argues that 'ideologies of language are rarely about language alone, but are socially situated and tied to questions of identity and power in societies'. It was evident that at this stage, English, power and material resources were conflated with 'whiteness' in students' minds. As a consequence of the Apartheid policy of 'separate development', many students still grow up and go to school in environments that have homogenous ethnic and language identities. They would have had little contact with 'white' people, and then only in situations where 'whites' were in control of the exchange both linguistically and materially. This is therefore an unsurprising reflection of an undifferentiated sense of otherness that characterised students' first encounters with an essentially foreign culture. Although over $50 \%$ of the university's student population is 'black', $75 \%$ of academic staff in Humanities are 'white' and many of the dominant institutional academic and cultural practices are still 'white' and male (even British) in character. 'Englishness' is the capital that is most visible to students and, in their eyes, it is owned by 'whites' and serves as a gatekeeper, both academically and socially.

For the students from township schools, the transition also represented their first encounter with 'black' people from middle-class backgrounds. When they first arrived, they were surprised to discover that some African-language speakers were using English in the informal social environment. In their first interviews, they spoke of how they felt intimidated when using English among African-language speakers from English-medium, 'model C' (formerly 'white', now racially mixed) schools. Sizwe stated, 'I was shy at first to speak English, I would be shaking . . . On the other hand, Noluthando, expressed anger about how 'white some black people are'. She was critical of how fellow 'African' students had taken on the English language: 'You do speak your language [to African-language speakers] and they respond in English, even with other Tswana speakers, they respond in English'. She narrated an incident where she and a friend were rebuked by a Xhosa-speaker for laughing "on top of our voices, saying, "Stop being so black."' Andrew, an Afrikaansspeaking, 'coloured' student from a working-class background, found himself alienated from other 'coloured' students whom he classified as 'middle-class and English' with a '. . . tendency of looking down upon people who come 
from underprivileged backgrounds'. For these students from working-class township schools, 'black' students from relatively elite English medium schools came to be associated with 'whiteness' (see also de Kadt, 2005 for a similar observation). Thus, Vuyani said:

I find it okay to communicate in English with my fellow blacks, but I'm scared to speak English in a large crowd of whites and those blacks called coconuts. 3 They judge you if you are not coming from a multiracial school but from a township school where English is taught as a second language.

The students' response was to assert a consistent, singular identity: that of their home environments (Bangeni \& Kapp, 2005). They identified themselves and others primarily on the basis of ethnicity/race and language. In her first essay on the relationship between language and identity, Bulelwa, a voluble person who struggled to make friends at university, used her dual Sotho/Zulu identity to explain her difficulty in social interaction: 'Even if you are a Zulu person who grew up speaking Sotho, people will not identify you with Zulu people. Instead they will see you as Mosotho because of the use of Basotho's [Sotho people's] language'. In many students' essays, identity was conflated with ethnicity, in others it was distinguished from the 'white', 'English' institutional environment. The following statements were typical:

People they can speak another language but they cannot forget their background or their identity. (S'busiso, Zulu-speaker)

People around you might influence your behaviour but they cannot influence your identity .... It is clear that that language a person chooses to speak can only influence his or actions. The identity remains unchanged. (Sizwe, Xhosa-speaker)

... I still strongly believe that the language you choose to speak cannot reveal your identity. It would take decades and decades for me to change this point of view, I can even publish a book about it. The other languages you choose to speak have nothing to do with your identity. (Vuyani, Xhosa-speaker)

Even though students were not asked to write about their personal experience, the 'l' in these early drafts is invariably self-reflexive. We see in these statements a defensive, possibly anxious, desire to preserve, not to 'lose' or 'forget' an original identity. A strong trope in many of the essays (and in our interviews) is the notion that it is possible to assume certain roles, to 'behave' in certain ways and to speak English in one's environment, without any consequent effects on one's core (ethnic) identity.

Whilst our students constantly emphasised the symbolic significance of their home languages, like the students in other recent South African studies (see Bangeni, 2001; Dalvit \& de Klerk, 2005; Dyers, 1999; Kapp, 2000) they were quick to point out the importance of English in their lives in terms of future access to resources and social mobility. Notwithstanding Vuyani's stated fears about speaking English and his averred strong allegiance to Black Consciousness, 4 he says in his first interview: 'I love Xhosa, I studied it at high 
school, I'm proud to be one [a Xhosa person] but I still feel we should be taught in English'.

This dual (and seemingly contradictory) motivation is fairly common in postcolonial contexts where the colonial language plays a powerful role in the dominant institutions. Gough (1996) draws on Heine to argue that among African-language speakers, the African language functions as a horizontal code Á an important signifier of social solidarity whilst English, the vertical code, signifies the potential for upward mobility. In Norton's (1997: 410) terms, the students are 'organizing and reorganizing a sense of who they are and how they relate to the social world'. In this understanding, motivation to speak a language is socially situated and often results in ambivalence because students are negotiating a sense of self in relation to multiple social realities. They are located in the alienating world of the academy in which they wish to succeed (through mastery of English), and the world (characterised by their home languages) in which they feel they belong, but which holds few opportunities for mobility. Significantly, these two contexts are by no means monolithic. Within the academy and at home, students are switching between and within multiple codes as they enact the multiple and fluid roles expected of them within both spaces. The students' fluency in English in their home contexts, as well as the context of a new political dispensation, have enabled them to be singled out for access to higher education and the possibility of significant social mobility, and yet, within the university environment their level of proficiency in the language places them in a deficit position.

\section{Straddling Two Worlds: 'Why Do You Speak English But You Are Black'?}

The students in our sample who went to racially mixed, English-medium schools (Andiswa, Babalwa, Dudu, Sisanda and Yandisa) are from very different class backgrounds and the schools they attended vary between elite, middle class and working class. Although their difficulties with academic literacy resulted in their placement on our course, all spoke and wrote English fluently and confidently compared to the students from working-class township schools. Nevertheless in their first interviews, they expressed a similar interest in maintaining (and not forgetting) their ethnic identities through connection to their home languages. According to Dudu, a Xhosa-speaker who was educated at a 'coloured', working-class school: 'At school we were not allowed to speak Xhosa, now I speak it everyday and I won't forget my roots, my mother tongue that's who I am, it's about my roots'. Sisanda, a Zuluspeaker, maintained that she 'wants to be known as umZulu and nothing else'. Yandisa, who was educated in an elite private school and whose parents are middle-class said: 'I was in a White school all my life but I have never forgotten who I am, my culture. I speak Xhosa, I am proud to be Xhosa, we have our culture which we practice at home, we still go to our rural roots on holidays'.

Although Yandisa's statement about the need to preserve Xhosa (and, by extension his Xhosa identity) is very similar in sentiment to that expressed by the students from township schools, in the same interview it became apparent 
that, like Babalwa and Andiswa, he hardly spoke Xhosa: 'I have Black friends whom I speak English to even though we both speak Xhosa as a mother tongue. It conflicts with who we are but none of us stops the other or questions the fact that we would switch to English all the time'. Yandisa came from a middle-class family background, where everyone was fluent in English. He also lived in the university's student residence and much of his socialising took place in the company of 'white' friends. Other than his trips to the rural homestead at holiday times, there was little in Yandisa's everyday practices that could be described as Xhosa in character. In the light of this, the description of his identity as Xhosa appears to be mainly symbolic. Although Yandisa conceived of identity in singular, static terms, he was identifying in multiple ways.

Similarly to the group from township schools, these students from racially mixed, English-medium schools, felt that English should remain the university's medium of instruction. However, the group was not homogenous in their personal language practices and attitudes. Dudu and Sisanda both felt liberated to speak their home languages in the informal environment after the constraints imposed by their schooling where English dominated both the formal and informal environment. Sisanda was unusual in that she spoke Zulu on and off campus and even took her lecture notes in Zulu.5

As in de Kadt's (2005) study, this group of students were aware that their use of English was being judged by students from township schools and by the community as a whole. According to Andiswa: 'I don't really speak Xhosa at all, yes there are some people who call us snobs and all of that because if you speak English then people become very negative, I don't know why'. According to Dudu:

\footnotetext{
When I'm sitting in a taxi with a friend who speaks Sotho and I'm going to elokishini [township] to like my home ... you speak English and these people start judging. They don't know this language you speak, they say: 'You are coconuts, why do you speak English but you are Black?' People really don't understand.
}

The students from township schools, who were so determined to maintain their home languages and identities, experienced similar rejection from their communities when they returned home after their first semester of university. Their fluency in English and/or the discourses of the Humanities, and in some cases just the fact of being at an elite university, suddenly cast them as outsiders. Many spoke of how their everyday conversation and perspectives had been influenced by the discourse of the academy. Noluthando said: '[my friends] think l'm not on their level anymore and some of them think I'm snobbish because now I'm out of the circle, I can look at them and I can now analyse them .... Vuyani, who in his first interview described Africanlanguage speakers from ex-model C students as 'coconuts', was shocked to find himself labelled in this way when he returned home for the vacation: 'Back home they now say I am a coconut, they have changed their attitude towards me' (Interview 2). This was because he had substituted Umhlobo Wenene (an African radio station) for Metro FM 'and as you know it's English'. Over time, the discourse of the academy comes to seem natural and 
commonplace to the students (Althusser, 1971). However, it is as they move between home and the university that the differences in ideology become visible again and they realise the extent to which they have been 'unhomed', locked into a '... doubling, dissembling image of being in two places at once... .' (Bhabha, 1994: 44).

Research in both South Africa (de Kadt, 2005) and Britain (Read et al. , 2003) has described how working-class university students experience 'feelings of "inauthenticity" in the institution and/or desires to retain all or part of a previous working-class identity whilst experiencing hostility from their home communities' (Read et al. , 2003: 267). For more middle-class students like Yandisa and Babalwa, this hostility was absent from their families and from their communities in the suburbs where people generally keep to themselves in contrast to the tightly knit, more ethnically homogenous character of working-class townships and rural villages (for detailed description, see Bangeni \& Kapp, 2005).

\section{Shifting Language Practices, Shifting Identities}

All of our participants passed their first year of study. From the students' second year onwards, there were noticeable differences in their confidence levels, their choices of lifestyle habits and their codes of dress, as they attempted to fit into the environment. All the students started to mix more freely across traditional ethnic and class boundaries. Many had part-time jobs and were able to acquire social goods such as cell phones, computers and brand name clothing, and concomitant social habits which would have been inaccessible previously. S'busiso's comment is typical:

... when I came here first I didn't worry about getting the clothes, like maybe the Levis, jeans and maybe e-h-h, Soviet, now I wear Soviet. You know, but something like this, gents, like they never said change your outlook but they influence. Like these guys, my friends, they influence. It changed my thinking because but now I think about what guys go for. (S'busiso, Interview 5)

These changes were accompanied by a shift towards use of English in everyday practices amongst the students from township schools. For workingclass students like Vuyani, there was a slow, but visible realignment as distinctions between 'whiteness' and 'Englishness' were made. In his second year he said: 'I think it's crazy this year most of the time I am using English . . . even with fellow Xhosa-speakers this year, ja [Afrikaans word for "yes"]'. Sizwe described in detail how his acquisition of a computer with a DVD facility enabled socialising with 'model C' black students. He said, 'even with my classmates, though they are Xhosas we don't speak Xhosa'. For the most part, students ascribed their changing language practices to the need to adapt to the environment. Dudu (Xhosa-speaking and educated at a 'coloured', working-class school) attempted to explain how she had acquired her 'model C' ('white') accent: 
Most of us come from different schools you know so the basis of language might be different and you are friends with these people so obviously l'm gonna adapt somehow [to] that kind of language and pick up some words. You know what I mean and the accent as well tends to change because ... yeah it just changes because you know [in the university] most of the people speak, they speak this you know what I mean [imitates 'model C' accent]. So now if you are here and you come from a disadvantaged school blah-d-blah and you come here with this type of English and you meet people who speak English very fluently and they have got this particular proper, what is regarded as proper accent and you spend time with these people the way you speak will, you know you are obviously gonna adapt, you are gonna use that sort of accent, not because you are forcing yourself to but because you are adapting to it.

Where Dudu had previously spoken about feeling liberated to use Xhosa in the U.C.T. environment, her view had changed to: 'I use English a lot now and it worries me. But it's okay because I know that I will never forget my language'. Eight months later she stated:

I haven't paid much attention to it. The thing is I wouldn't say it bothers me [not using home language]; it is something that I don't do intentionally whereas if I did it intentionally it would bother me a lot. It's not that I've forgotten about my language, it's not that I don't know how to speak it anymore. I promise you I can speak it 100\%, you understand that there are many people who don't understand their own language and I am happy that as long as I know where I come from and still know my language l'm happy.

Here Dudu seemed to be attempting to convince both Bongi (her interviewer who is also a Xhosa-speaker) and herself that her infrequent use of the language had not affected her Xhosa identity. She was careful to distinguish her position from those African-language speakers who, in her view, are so alienated that they cannot speak their home languages.

In a focus group interview conducted in the latter half of their second year, students from the township schools spoke of how they could not always remember words in their home languages whilst in the university environment. Noloyiso, a Swati-speaker, spoke of how she had recently found that she could not remember the word for the number 'eight' in her home language. She accounted for this by saying that she had very few opportunities to speak siSwati at university because there are so few speakers. She added that she often thinks and dreams in English: 'It's so spontaneous, it just flows'. Three more students narrated instances where they had not managed to compose in their home languages. In contrast to the anxiety expressed in their first year, the students' anecdotes were marked by humour and self-irony and were rewarded with ribald laughter. Andrew ended his story by adding 'It's become so part of us, it's almost natural . . . it's because of the environment we're in ... at the end of the day we compromise'. Students then spoke of how they changed both language medium and behaviour, as they moved between 
home and university. In Andiswa's words 'you just have to adapt and adjust', in Andrew's words 'you alternate identities back and forth all the time'.

In this interview the students from township schools also spoke about how they are now accused of being 'coconuts' by friends at a neighbouring historically 'black' university. When asked whether this was a valid descriptor, students chorused 'no', responding indignantly to what they viewed as an accusation. In Andrew's words: 'Being a coconut is not about language, it's about class', to Lesedi, a Tswana-speaker: 'it's about accent'. Surprisingly, students' explanations of their shifts in identity were fairly congruent with the notions expressed in their first interview: that they may behave differently, but that their original (ethnic) identities nevertheless remain intact, that they were still able to retain (not forget) a connection to home identities despite the hostility that many of them have experienced since coming to university. The disaggregation of English from 'whiteness' in their discourse was increasingly reminiscent of that of the students from racially mixed schools (whom they had described as 'coconuts' in their first year).

Interestingly, the students' descriptive language ('adapting', 'adjusting', 'alternating' identity) was strongly drawn from one of their first-year introductory courses which used the discourse of Religious Studies to describe how people predominantly alternate identity (behaviour) in multiple contexts as opposed to undergoing conversion (a complete change of belief system), which is regarded as rare (Travisano, 1970). Although it accepts the idea that individuals adopt different identities in different situations, this conception maintains the notion of a norm in which new ideas are added on to an established identity or in which new identities replace old ones in expected ways. It does not engage with the post-structuralist notion that individuals may maintain multiple identities. In their longitudinal study of undergraduate students, Herrington and Curtis (2000) argue that individuals tend to present their identities as coherent, singular and stable. The students in our study appropriated Social Science discourses to rationalise and neutralise their ambivalent positions, thus jointly reconstructing their biographies and creating a narrative of natural progression. Each year we asked them whether they believed they had changed. The stock response was to assert: 'I've grown'.

\section{Emerging Discourses and the Implications for Identity}

Although all our participants were using English more and more often in their social contexts by their second year, the students from township schools also expressed a strong desire to retain their home accents. Andrew became very upset when, in his second year, a fellow 'coloured' student suggested that he had 'lost' his 'coloured' accent; and he went around checking to see whether his friends shared this view.6 Andrew started to teach Afrikaans to Andiswa (an 'ex-model C' student who previously hardly spoke Xhosa) and he, in turn, started to learn Xhosa from her, Michael and Sizwe.

Students from both the township and racially mixed schools maintained in interviews that they spoke mainly English. However, we observed that in informal situations in their senior years, they codemixed between English, 
Afrikaans and Xhosa,7 interspersed with Kwaitos-derived slang to such an extent that we struggled to follow their exchanges. We asked students about this in subsequent interviews and discovered that they were quite conscious about doing so, but had not remarked on it in interviews because English formed the primary base language of their exchanges. Referring to a popular 'new' South African youth soap opera in which codeswitching and codemixing is a regular feature of the discourse, Andrew described the shared code as 'Backstage language'. Dudu described it as an insider language: 'when you are with a group of friends, people that speak your own language, you can slang without having to check if you are understood'. Sizwe called the shared code, 'Kaaps', a term conventionally used to describe the variety of Afrikaans spoken by 'coloureds' on the Cape Flats. He said: 'We enjoy doing that when we are sitting down and having some conversation, we use that language. People use it as some sort of in between language. People are using English but a certain style of English, they are sort of Africanising it'. The new code, it seems, allowed students to feel comfortable using English because they were simultaneously signalling their Africanness. What was interesting about this form of language use is that it enabled them to feel comfortable connecting across both conventional ethnic barriers and the perceived class differences that exist between students from township schools and those from racially mixed schools.

Blount (1995: 50) argues that:

In between the recognized dialect or language as a whole and the individualized speech of a given individual lies a kind of linguistic unit which is not often discussed by the linguist ... This is the subform of a language which is current among a group of people who are held together by ties of common interest.

Although we have not conducted a linguistic analysis of the 'subform', we believe that the fact of using a shared code signifies students' dual affiliation to the symbolic capital that resides in English (with all its connotations of being educated, modern and upwardly mobile) and to the notions of authenticity and belonging that their home identities represent. In mixing languages across boundaries of school background and across traditional ethnic barriers, the new code also signifies their shared hybridg group identity as first-generation university students in post-Apartheid South Africa. Although the sample is small, it does contest easy classifications of students as assimilated to 'Englishness'.

Another interesting feature of students' final year is that their multilingualism and township roots suddenly became a resource when they were required to conduct fieldwork research. They recognised that for the first time they were at an advantage compared to their 'white', middle-class peers in terms of gaining access and in terms of the quality of data they were able to collect. In Bourdieu's (1991) terms, for the first time, their 'cultural capital' became 'symbolic capital'. 


\section{Conclusion}

In this paper we have tried to show how the shifts that occur in the language attitudes of second-language speakers of English are connected to a range of social factors and individual experiences and emotions. The 'Englishness' of the university environment plays a crucial role in their shifts. We show how, over time, home discourses make way for the more dominant discourses of the institution which are perceived as being socially advantageous. English signifies social mobility as opposed to their home languages, which play a more symbolic role. The dual desire, that is, to be fluent in English Á which is central to the attainment of academic literacy Á and the simultaneous allegiance to their home languages and identities reflects the ambivalent position students find themselves in as they attempt to shift between discourses. Their construction of a shared code is an expression of a jointly constructed hybrid space, which bespeaks their ambivalence and the consequent attempt to reconcile home and multiple institutional subject positions. The new code facilitates group identification and solidarity. In Bhabha's (1994: 44) terms, the students have become 'unhomed'. However, as he argues, the term does not imply homelessness, but signifies a third position, that is, the ambivalent space they occupy as they straddle multiple (and often conflicting) discourses.

The move to promoting African languages in the learning environment needs to take into account that the sociopolitical changes in South Africa have resulted in hybrid identities that influence how people use language; and how they perceive their own languages alongside English, which is firmly entrenched as the primary language in the dominant institutions. Alongside other recent studies (Dalvit \& de Klerk, 2005; de Kadt, 2005; Dyers, 1999), our data show that English continues to enjoy a privileged position among secondlanguage speakers, a situation that will be hard to interrupt as the instrumental benefits remain obvious. Another important observation is that among Africanlanguage speakers, there are those who may not necessarily perceive the use of African languages for learning as contributing to better academic conceptualisation. As the transition to democracy has ensured that 'black' people, albeit a minority, also have access to good quality education, English is not necessarily seen as a threat or a barrier to learning for this group. This means that African languages are then relegated to the backseat, mainly called upon to signal affiliation and loyalty to an ethnic group. When one juxtaposes the students' symbolic acknowledgement of their home languages with the quest to be members of the discourses they encounter at university, it becomes evident that language policies that espouse multilingualism for learning need to take into consideration the nuanced nature of the linguistic identities of English secondlanguage speaking students in historically 'white' institutions. The policies also have to take cognisance of the ways in which school backgrounds influence language attitudes, practices and access to resources.

\section{Acknowledgements}

We are grateful to Kelwyn Sole, Ermien van Pletzen and our anonymous reviewers for invaluable comments on our first draft. This material is based upon work supported by the National Research Foundation (under grant 
number 2054167). Any opinions, findings and conclusions or recommendations expressed in this material are those of the authors and therefore the NRF does not accept any liability in regard thereto.

\section{Correspondence}

Any correspondence should be directed to Rochelle Kapp, Academic Development Programme, CHED, Hlanganani Building, University of Cape Town, Private Bag, Rondebosch 7701, South Africa (rochelle.kapp@uct.ac.za).

\section{Notes}

1. It is impossible to contextualise fully the imbrications of South African language and educational backgrounds without using the Apartheid-era racial classification ('African', 'Coloured', 'Indian' and 'White'). However to signify our own beliefs that these categories are to some degree at least, artificially constructed, we will use quotation marks. In this paper we use the category 'black' inclusively to refer to 'African', 'Coloured' and 'Indian' students.

2. Until 1996, there were 19 separate education departments in South Africa. Broadly, schools located in townships designated for 'African' people were administered by the Department of Education and Training (D.E.T.), and those designated for 'coloured' people were administered by the Department of Education and Culture (D.E.C.). Both were under-resourced and notoriously corrupt. In 1991, the State allowed formerly 'whites only' schools to choose between three models. 'model C' used to refer to those former 'white' schools that opted for a model that allowed for a 49\% 'black' enrolment and semi-private status. However, post-1994, 'model C' has become a generic term for all schools that were designated for 'whites'. In our data, students often use 'model C' synonymously with 'white'. See also Kapp (2000).

3. This is an originally American term used to refer to a 'black' person who is perceived as acting 'white', that is, s/he is black on the outside but white on the inside.

4. A political movement, which rose to prominence (under the leadership of Steve Biko) in the 1970s in South Africa and which attempted to recover a black identity in defence against 'white' political, economic, cultural and psychological domination.

5. Sisanda stands out as an exception in our data because she maintains this position throughout her undergraduate years. For a detailed analysis, see Bangeni and Kapp (2005).

6. Interestingly, both Dalvit and de Klerk (2005) and de Kadt (2005) comment that among the Xhosa and Zulu speakers in their study, accent is considered an important signifier of African identity.

7. English, Afrikaans and Xhosa are the three official languages of the Western Cape.

8. Kwaito is a local music form which Nuttall (2004: 433) describes as 'a potent blend of city and township sound that emerged after the democratic transition in 1994, mixing up the protest dancing and chanting known as toyi-toyi with slow-motion house, local pop ("bubblegum") and a dash of hip-hop'.

9. Nuttall (2004) has similarly described emerging hybrid cultures among black South Africans as they signal township and city identities.

\section{References}

Althusser, L. (1971) Lenin and Philosophy and Other Essays (B. Brewster, trans.) London: New Left Books.

Baker, C. (1993) Foundations of Bilingual Education and Bilingualism. Clevedon: Multilingual Matters. 
Bangeni, B. (2001) Language attitudes, genre and cultural capital: A case study of EAL students' access to a foundation course in the Humanities at UCT. Masters thesis, University of Cape Town.

Bangeni, B. and Kapp, R. (2005) Identities in transition: Shifting conceptions of home by black South African university students. African Studies Review 48 (3), 1 Á19

Bangeni, B. and Kapp, R. (2006) 'I want to write about the Dalai Lama without being penalized?': Literacies in transition. In L. Thesen and E. Van Pletzen (eds) Academic Literacy and Languages of Change (pp. 67Á83). London: Continuum Press.

Bhabha, H. (1994) The Location of Culture. London: Routledge.

Blount, B.G. (1995) Language, Culture and Society. Illinois: Waveland Press Inc.

Bourdieu, P. (1991) Language and Symbolic Power. Cambridge, MA: Harvard University Press.

Canagarajah, A. (1999) Resisting Linguistic Imperialism in English Teaching. Oxford: Oxford University Press.

Dalvit, L. and de Klerk, V. (2005) Attitudes of Xhosa-speaking students at the University of Fort Hare towards the use of Xhosa as a language of learning and teaching (LOLT). Southern African Linguistics and Applied Language Studies 23 (1), 1 Á18.

de Kadt, E. (2005) English, language shift and identities: A comparison between 'Zuludominant' and 'multicultural' students on a South African university campus. Southern African Linguistics and Applied Language Studies 23 (1), 19 Á37.

Department of Education (2002) Language Policy for Higher Education. On WWW at www.education.gov.za [2007, June 2].

Dyers, C. (1999) Xhosa students' attitudes towards black South African languages at the University of the Western Cape. South African Journal of African Languages 19 (2), 73 Á83.

Gee, J. (1990) Social Linguistics and Literacies: Ideology in Discourses. London: Falmer Press.

Gough, D. (1996) Black English in South Africa. In V. de Klerk (ed.) Varieties of English Around the World: Focus on South Africa (pp. 53Á78). Amsterdam: John Benjamins Publishing Company.

Herrington, A. and Curtis, C. (2000) Persons in Process: Four Stories of Writing and Personal Development in College . Urbana, IL: National Council of Teachers of English.

Hirson, B. (1979) Year of Fire, Year of Ash Á The Soweto Revolt: Roots of Revolution? London: Zed Press.

Kapp, R. (2000) 'With English you can go everywhere': An analysis of the role and status of English at a former D.E.T. school. Journal of Education 25, 227 Á259.

Kapp, R. and Bangeni, B. (2005) 'I was just never exposed to this argument thing': Using a genre approach for teaching academic literacy. In C. Moran and A. Herrington (eds) Genre Across the Curriculum (pp. 109Á127). Utah University Press.

Kress, G. (1989) Linguistic Processes in Sociocultural Practice . Oxford: Oxford University Press.

Le Page, K. and Tabouret-Keller, A. (1985) Acts of Identity: Creole-based Approaches to Language and Identity. Cambridge: Cambridge University Press.

McGroarty, M. (1996) Language attitudes, motivation and standards. In L. McKay and N. Hornberger (eds) Sociolinguistics and Language Teaching (pp. 3Á46). Cambridge: Cambridge University Press.

Morgan, B. (1997) Identity and intonation: Linking dynamic processes in an ESL classroom. Tesol Quarterly 31 (3), 431 Á450.

Ndebele, N. (1987) The English language and social change in South Africa. English Academy Review 4, 1 Á16.

Norton, B. (1995) Language learning, social identity and immigrant women. Tesol Quarterly 29 (1), 9Á31.

Norton, B. (1997) Language, identity and ownership of English. Tesol Quarterly 31 (3), 409 Á430.

Norton, B. (2000) Identity and Language Learning: Gender, Ethnicity and Educational Language. London: Longman. 
Nuttall, S. (2004) Stylizing the self: The Y generation in Rosebank, Johannesburg. Public Culture 16 (3), 430 Á452.

Pavlenko, A. and Blackledge, A. (2002) Introduction. Multilingua 21 (2/3), 121 Á140.

Pavlenko, A. and Blackledge, A. (eds) (2004) Negotiation of Identities in Multilingual Contexts. Clevedon: Multilingual Matters.

Read, B., Archer, L. and Leathwood, C. (2003) Challenging cultures? Student conceptions of 'belonging' and 'isolation' at a post-1992 university. Studies in Higher Education 28 (3), 261 Á277.

Republic of South Africa (1996) The Constitution of the Republic of South Africa, no. 108 of 1996. On WWW at www.info.gov.za/documents/constitution/ [2005, May 25].

Travisano, R. (1970) Alternation and conversion as qualitatively different transformations. In G. Stone and H. Farberman (eds) Social Psychology through Symbolic Interaction (pp. 594Á606). Waltham, MA: Xerox College Publishing.

Young, D. (1995) The role and status of the first language in education in a multilingual society. In K. Heugh, A. Siegruhn and P. Pluddemann (eds) Multilingual Education “.. for South Africa (pp. 63Á70). Johannesburg: Heinemann. 